\title{
Sufism Methodology \& Its Educational Applications
}

\author{
Omar Al-Khateeb, Ph.D. \\ Prof. of the University Requirements \\ Al-Hussein Bin Talal University
}

Received: Nov. 3, 2019

Accepted: Dec. 3, 2019

Published: February 1, 2020

doi:10.5296/jse.v10i1.15726

URL: https://doi.org/10.5296/jse.v10i1.15726

\begin{abstract}
The study aimed to measure the impact of the Sufism educational methodology the Sufism educational methodology is an intellectual phenomenon, which was the result of special, political, mental \& social circumstances that the Muslim nation experienced in the past; these circumstances are very close to the current political, mental \& social circumstances that Muslim experience nowadays. The results of the study show that The Sufism educational methodology presents a practical method that aims to providing students with psychological education, which, in turn, attempts to investigate the motives behind people's bad deeds and to get rid of these deeds. This indicates that the Sufism educational methodology has shifted the educational concern from the pure physical teaching problems to the investigation of the psychological problems.
\end{abstract}

Keywords: Sufism, Sufism Development Sufi Educational Curriculum, Educational Applications. 


\section{Introduction}

The concepts and areas tackled in the Islamic Culture course at Jordanian universities have their distinguished impact on students' life since they contain all the Islamic religion concepts.; such concepts focus mainly on the true belief rules which include the belief in God, angles, the heaven books, resurrection, punishment, heaven, hill, and fate. They also contain the scientific provisions that organize people's actions, sayings, \& legal and prohibited actions. Furthermore, they include moral aspects as complementary to Islam.

It can be said that all of these provisions can be used to judge student's knowledge \& their behaviors \& morals. It is important to mention that these concepts aim to provide the minds with the absolute facts about this religion amidst the fake arguments and ideas that have spread about Islam recently. Again, they aim to strengthen the true principles, systems, methodologies, \& they to distinguish between what is right $\&$ what is fake. Therefore, these concepts attempt to introduce students to the useful elements \& get rid of the harmful \& corrupted ones. As such, the Islamic concepts play an effective role in rising the youth on right religious bases \& enhancing their Islamic convictions \& values so as to become integral aspects of their daily life.

It is possible to distinguish between the Islamic teachings concerning individuals and those of societies. As for individuals, the Islamic concepts seek to ensure that a Muslim:

- Believes in God and fears His punishment;

- Is moderate, and is able to get rid of all kinds of extremism, selfishness or oppression;

- $\quad$ Is satisfied with his/her fate; \&

- Is a true believer in what God has told us about the metaphysics and the Day of Judgment.

At the society level, the Islamic concepts seek to form the community that experiences the following traits:

- Activity and constructiveness: in accordance with the teachings of the Holy Quran, the Muslim community must be active and influential as stated in the following verse:

"You are the best of the nations raised up for (the benefit of) men; you enjoin what is right and forbid the wrong and believe in Allah; and if the followers of the Book had believed it would have been better for them; of them (some) are believers and most of them are transgressors. Consolidation: the Muslim community must be consolidated." (Surat AL Imran, verse: 110 )

- Constructivism: the Muslim community should do its best to improve the life of its population and fight all means of corruption. Furthermore, the Muslim society is responsible for the protection of the nation's the achievements and the individuals' dignity. 
- Security: the society must enjoy all aspects of security that, in turn, respect the individuals' privacy and rights.

The Islamic concepts aim also to put an end for the human disasters, \& overcome their real reasons through what they present of high level morals, \& fair divine provisions \& legal effective solutions (Al-Najar, Abdullah, \& Saleh, 1993). Definitely, these concepts will help students to face the challenges of globalization and other reasons that led to the appearance of a lot of seditions \& intellectual terrorism.

Due to the importance of the Islamic concepts in students' life as a source of knowledge, principles, theories \& generalizations, \& also as a way to develop the students' ability of thinking \& to upgrade the level of morals among individuals \& groups, special attention must be paid to how these concepts are presented to students. For instance, it is quite important to focus on the spiritual dimension while presenting these concepts. Evidence in literature indicates that the spiritual dimension forms a fundamental motive for human behavior.

In spite of the centrality of the Islamic educational concepts \& the important use of the modern teaching methods, which call for forming a new learning environment that concentrate on the students' role, make them the pivot of the educational teaching \& learning processes, develop their basic mental capabilities to organize knowledge \& form an integrated conceptual structure (Eshtaiwah,1999; Omari, 1990; Khawaldeh, 1989, among others), the teaching methods are still mainly devoted to presenting these concepts, general facts \& information, with little concern with the students' moral education.

\section{Problem of the Study}

The researcher noted throughout his teaching of the Islamic Education course at Al-Hussein Bin Talal University for more than five years the existence of several problems facing the learning process of Islamic Education concepts. This emerges clearly by the gab between what the students learn $\&$ their effect of this on their lives $\&$ behavior adjustments.

\section{Importance of the study}

The importance of this study stems from the following elements:

1. Its compliance with the educational trends \& interests in the Islamic education subject, which call for the necessity of using new teaching methods to face the contemporary challenges in order to provide students with the scientific skills \& the moral education.

2. The Sufism educational methodology is an intellectual phenomenon, which was the result of special, political, mental \& social circumstances that the Muslim nation experienced in the past; these circumstances are very close to the current political, mental \& social circumstances that Muslim experience nowadays.

3. The Sufism educational methodology presents a practical method that aims at providing students with psychological education, which, in turn, attempts to investigate the motives behind people's bad deeds and to get rid of these deeds. This indicates that the Sufism 
educational methodology has shifted the educational concern from the pure physical teaching problems to the investigation of the psychological problems.

\section{Sufism Development}

Sufism is considered one of the legal or religious Islamic sciences, like sciences of speech, jurisprudence \& interpretation; Sufism has many names such as the Science of Morals, Science of Realities, Conditions, Self-epidemic, \& self-knowledge. However, Sufism remains the most used name. There are several reasons behind calling this sect Sufism. However, the closest name for Sufism comes from "wool", because wool is used as the primary clothes of its followers. Put it differently, this name is very close to modesty, \& asceticism terms.

Sufism seems to be a practical behavior represented by complete adherence to the correct legislations \& getting rid of ornaments, as a response to the dissoluteness life which most people sunk in during the Abbasid era (Ibin-Khaldoon, 4967.AC). Faithful people at that era established their own way, by complete adherence to the teachings of the Holly Quran, \& the traditions of the Prophet Mohammad. Those followers called to discard that materialistic life $\&$ return back to the prophecy's methodology.

The teachings of Sufism call upon its adherents to fight the materialistic aspects of life and to focus solely on the simple means of life. Adherents of this sect believe that human beings cannot understand his/her luminous existence unless they get rid of ornaments and decorations of life. Al-Romi (quoted in Lincoln, 1951) states that:

"Sterilize yourselves from selfishness in order to see your luminous existence. Yes, you see in your hearts, the prophet's science without a book, \& without a teacher or director."

However, Sufism witnessed numerous changes across time. commencing the late second Hegira Century (Helal, 1975) and as a result of the effect of many philosophies such as the Indian Vedanta, \& the Persian Brilliance, Plato, the Gonousian Knowledge, \& Christianity asceticism \& Buddhism's ideas of Contemplation \& Extinction. These philosophies brought into Sufism a number of influential ideas and methods such as inundation, brilliance \& knowledge, \& the Substitution belief \& unity of universe (Jalal, 1990).

Numerous pieces of evidence provide concrete support of the influence of the previous philosophies on Sufism. Abu-Yazeed Al-Bustami, for instance, explicitly presents the notion of the unity with God (Al-Qaishari, 1980). Al-Halaj, on the other hand, focuses on the substitution notion:

"Each person who corrects himself by obeyness, \& fill his heart with right actions, \& is patient in discarding enjoyment's, \& controls himself to avoid appetites, he will be raised to the position of the closest people, he will continue refining himself until his nature will be raised above the humanity level. Once he has spiritually become better than human beings, the soul of God will occupy him, as the Christ, son of Merriam, who was from the God's soul, then he will be obeyed, $\&$ if he wants any thing he will get it according to the will of God. At 
that stage, all of his actions are the actions of God \& all of his commands are the commands of God." (Helmi, 1945).

Sufism Main Assumptions,

Sufism thinking is based on many assumptions. Following are the most important of these assumptions:

\section{(i)The human being consists of two worlds: the world of body, \& the world of soul.}

This intensified body belongs to our world; it is created from dust \& will end as dust. However, the soul does not belong to this world, it comes from the heavens. As such, the human being consists consist of two different elements, or two different essences, namely, the material \& the soul. The intensified materialistic body is a prison; the soul has been imprisoned in it (Al-Ghazali, 1960).

The release of the human being $\&$ his happiness lie in the release of the soul from its prison. However, while in prison, the soul keeps looking forward to contacting its heavens $\&$ to be released from this prison. Therefore, the primary goal here is to break the intensity of the body in order to release the soul to its realm (Tseher, 1970)

(ii) Sufis assume that there is an absolute fact that can be known \& contacted:

Unlike the experimentalists, who confine the human knowledge to the experiments, or materialists, who confine the knowledge to the sensory experiments, or even the rationalists, who want the knowledge to be confined to the mind alone, Sufis state that there is an absolute fact that can be known \& contacted.

However, it is important to mention that Sufis don't deny the capability of the human being to seek for knowledge via senses, experiments \& minds, but they view these pieces of knowledge are not complete (Lincoln, 1951). Therefore, science, logic, philosophy are unable to grasp the realities of things in the same sense of the divine knowledge. As such, the only way to get introduced to such absolute facts is the heart, which is the only road for the certain knowledge, or the right knowledge; it is similar to the bright mirror which reflects all pieces of God's knowledge (Al-Ghazali 1950).

The heart is the only reliable organ that can be addressed or even asked in accordance with the verses of the Holy Quran:

Allah does not call you to account for what is vain in your oaths, but He will call you to account for what your hearts have earned, and Allah is Forgiving, Forbearing. (Surat Al Baqarah, Verse 225).

(iii) Sufism sees that the way to reach the absolute fact is to disobey the person's inferior characteristics. People should promenade themselves from their offensive acts \& their malicious characters until the separation of the heart from everything else around it except the God. This means that the heart should be disconnected from the divine $\&$ to be directed completely to the God. (Al-Selmi, Manuscript). 
(iv) The self powers do not work separately from each others. Each power performs a function within the frame of the humanitarian, spiritual \& physical integration, which guarantees happiness for the human being. However, some functions are served \& the others are servants. (Ottoman et al,, 1958; Al-Tarmathy, Al-Bani, 1947, among others).

\section{Sufi Educational Curriculum}

The Sufi educational curriculum in its essence is based on a special spiritual nurturing, \& self preparation. In order to be connected with God, the Sufi should seek \& sense the self diseases. He should also know them in order to fight them, because self commands are offensive according to the verses of the Holy Quran:

"And I do not declare myself free, most surely (man's) self is wont to command (him to do) evil, except such as my Lord has had mercy on, surely my Lord is Forgiving, Merciful." (Surat Yousif, verse 53).

Therefore, all the motives \& human instincts should be purified in accordance with the principles of submission and surrender to God. This means that these teachings aim at organizing all Moslem's behaviors \& subjugate their motives to the love of God, \& to follow His commands \& discarding His constraints.

Al-Jnaid says: "The person exists long before his appearance in this materialistic world. The human being in the previous world believes in God \& s/he confirmed His monotheism before the creation of this materialistic world. God addressed our souls, which are not existent without Him. The God brought down these souls from the heavens to our world, \& dressed them with their bodies for testing and death purposes. Some of these souls were occupied by divine matters \& forgot their origin \& there home, but some of them missed their homeland $\&$ wanted to return back to that origin, \& made their aims to fulfill that conviction with God $\&$ wanted to return to their previous state before the existence of this world. Once the souls are extinct from their chronicle existence \& remain with the God, then meaning of pure love for God will be fulfilled. (Al-Bairouni, 1958; Al-Selmi, Makhtoot, among others).

The Sufis educational curriculum seeks to concentrate on the religious emotions so as to make it them more dominant than all other emotions and it also organizes all the self motives under this prevailing \& eminent emotion. Again, it exploits all Moslem's activities \& motivates their talents to return back to God with the aim of fulfilling their satisfaction in everything they do in order to raise his reality \& his nation's reality, \& to get red of the deterioration \& the materialism which prevailed the Islamic nation." say that my praying, my worship, my life \& my death are for go of all people "(Surrat Al-Anam: 63).

Therefore due to this nurturing which integrates the power of oneself, the Sufi educational curriculum makes the personality of the Moslem much more cohesive, a personality that doesn't know hesitation, \& does not fall in the interior conflict, or the psychological conflict when he connects his heart with God \& makes him trust God who created the heavens \& earth as indicated in the verses of the Holy Quran: 
"Allah sets forth an example: There is a slave in whom are (several) partners differing with one another, and there is another slave wholly owned by one man. Are the two alike in condition? (All) praise is due to Allah. Nay! most of them do not know." (Surrat Al-Zamur: 29)

In this verse, God shows that the person who is owned by more than one master, who are, in turn, opponent cannot behave properly as every master orders or asks him to obey him. The motives and instincts of a human being who is controlled by greediness, attitudes \& appetites, $\&$ materialism will be always controlled by these different considerations.

\section{Ways of Building \& Nurturing the Religious Emotions}

Sufism sees that forming the religious passion requires repetition, reaction, concentration, \& waking up certain motives to be joined under this passion. The passion might become an independent and satisfactory belief that attracts followers here and there if its formation must wake up the mental factors to support it, \& this passion must be supported by the practical evidence, according to the Islamic pillars \& regulations. Worship, actions \& Islamic education prove the conviction, \& strengthen the connection with God, \& strengthen the passion towards Him \& His fondness. This conveys that the religious passion educates the instinctive motives, \& strengthens the personality \& gathers all the capacities \& motives \& directing them for one direction as stated in the following verse from the Holy Quran:

"And (as for) those who strive hard for Us, We will most certainly guide them in Our ways; and Allah is most surely with the doers of good." (Surat Al Ankabout, 69)

Worships form the best tools for the straight path, as Prophet Mohammad says:

"As long as my servant approaches by worships until I love him. And once I love him, I will be his ears, \& his vision." (Al-Bukhari, Chapter of: Indications for God's love of the servant.").

\section{Sufism followed many methods to fulfill its objectives:}

(i) Knowledge

The Brilliant Sufi Knowledge: this aims to uncover the secrets of the divine knowledge, \& the evidential sciences. The highest level of these pieces of knowledge is the knowledge of God, which is an end for any Muslim (Badawi 1975(Al-shathely, 1977, among others).

The Sufis assume that the belief in God must be based on real knowledge. Once this happens, the belief becomes the motive for the behavior (Ebin Hazm, 1980). Therefore, the Sufis firmly believe that knowledge is so vital for Muslims since it forms the basis of religious \& moral, \& worship principles, $\&$ it is also base for the necessary principles of asceticism in order to be directed toward the epistemology which requires uncovering all hidden matter. In this regard Al-Juneid says: "All the roads are closed in the fact for all people except those who follow the track of Prophet Mohammed. (Al-Qushairy, 1980).

He also says: "My Sheikh Al-Seri asked me one day: If you leave me now with whom you are going to sit? I, answered with the Al-Muhasibi, then he said, yes make benefit of his 
knowledge \& politeness, leave his verbosity \& his responses to the talkative people then he said: I pray to God to make you a man who knows much about Sufism, but not a real Sufi. For him getting the knowledge first and then to become a Sufi is better than becoming a Sufi and then to get knowledge (Al-Ghazali, 1950).

Abi-Al-Hussein Al-Nouri was asked: how did you know God? He said: by god himself. He was also asked: How about mind? He said: the mind is handicapped, does not indicate to any thing except for a handicapped like it. In this regard, Di -Alnoon Al masri says: "I know my God by my God without my God I would not know God.” (Lincoln, 1951).

Mind cannot recognize God because it is an inferential power that might be right or wrong; it is limited \& confined with his inferential and how can the confined recognize the unconfined. The mind is limited because it is connected to the material to an extent it is connected with the cerebrum. Knowledge is connected with extinction; Abu Yazeed Al-Bustami said: I went for pilgrimage for the first time, I saw the Kaaba, \& I went for pilgrimage again, I saw Kaaba $\&$ its owner, in third time I saw neither the Kaaba, nor its owner. (Al- iasaturi, 1950). Therefore, the first step in his journey to reach knowledge is the sensory stage in which he saw the Kaaba \& he recognized it in a sensory manner. In the second time, he recognized Kaaba \& its owner (he recognized this two, \& discriminated between God \& the world, because the mind indicates the existence of a creator. However, in the third time, he recognized the two by his heart \& he did not discriminate between the Kaaba \& the owner. As such, the knowledge order is as follows:

- sensory recognition

- mental recognition

- Recognition by heart, \& the last stage represents the perpetuity

The way for removing the barriers \& bringing back the heart to its pure state requires getting rid of all characteristics and deeds and resisting all kinds of temptations (Al-Ghazali, 1950). Carrying out this mission requires two things:

- Materialistic behavior of the body.

- Spiritual behavior of the soul.

As for the spiritual aspect, a person should work hard to purify his soul from all kinds of corruption and should also seek forgiveness from God (Al-Qasheeri, 1980). However, the materialistic aspect is devoted to the purification of all kinds of speeches and works. This requires getting rid of all sins including adultery and all other forbidden deeds (Al-Tarmidi, 1947).

\section{Secondly: Love}

It is the maximum end of the worshipping. This lies in the love of God and this, in turn, requires stopping all other relations with this materialistic world. Once a person reaches this level, the world will become no more than a prison for his/her. This conveys that this person will do his best to escape this prison and join his God. No doubt, love forms the largest 
motive for doing what is good and stopping what is evil. This requires that we understand that we need God every single minutes and God only has the power of everything in this universe. When a Sufi worships his God, he knows that God is the only source of happiness in this world and He is the only power to prevent him from committing sins. As such, the person who loves God will do only what is good and will always seek His forgiveness (Al-Gushairi, 1980).

Passion of love increases once we receive pleasant actions repeatedly. The more we receive such actions, the more we love the donor. This is psychologically confirmed; the psychologist Kant asserts that: "let us firstly start with teaching the boy how to know God by giving examples, \& advise him that God is like the father towards his children; He takes care of them \& He is merciful towards them (Modern Muslim Magazine 1976).

No doubt fondness has significant role in directing the behavior. Dr Alexes Karl states that there are only two constructive passions, namely, the passion of love $\&$ the passion of fear. Love only has the capacity to remove barriers, \& make us happy. The child's love of his mother will motivate him to modify his behavior (Modern Muslim Magazine 1976).

\section{Results and Educational Applications}

Following are the most important results achieved via studying the Sufi educational curriculum:

1- Introducing and reminding students with the verses of the God \& His subsistence so as to strengthen their relations with God and follow His straight path.

2- $\quad$ The belief that interweaves passion with mind will strengthen the learners' belief in God.

3- Rising the Islamic emotions in all academic situations is important to form and nurture the religious emotions.

4- Performing the person's duties for the sake of God strengthens the learner and motivates him/her to establish life with dignity \& build the moral education in our schools.

5- Concentrating on the causes of God's love will result in the formation of the religious passion.

6- Rising the interior reactions, awakening passion \& purifying the motives are necessary in the education process.

7- $\quad$ The teacher must be always convincing, he should discuss the lessons politely \& seeks to raise the educational level of learners \& to remove all the barriers blocking the way of the desire (like fanaticism, stubbornness, arrogant $\&$ the sensory view to the matters).

8- Introducing learners to the fact that the belief in God is quite beneficial for people and their interests.

9- $\quad$ Directing the physical \& mental practices to prepare good and responsible learners, who believe in wisdom 


\section{Educational Applications}

Based on the research and concern of Sufis with human behavior, innate motives, knowledge of God, society and environment, it is possible to conclude that the Sufi educational methodology was the source of the current psychological and educational studies (Othman et al, 1958). Drawing on the preceding sections, it is possible to highlight six of the most important education applications of Sufism educational methodology.

\section{First: Concept of Education}

Sufi education aims to achieve the highest level of human perfection via the intimate relation with God and taking Him as a guide.

Second: Objectives of the Sufi Education

The Sufi education aims at pushing people to get closer to God through acquiring the virtues $\&$ the good manners. It also aims at reforming the person's life \& developing the human personality.

\section{Third: Learner}

Learner must be an ideal example and s/he must apply what he learns in his life. Again, the learner must free himself from all bad deeds.

Fourth: Teacher

Teacher is one of the most important pillars of the educational process. The teacher should be an adviser for his learners \& is able to persuade them.

Fifth: Methodology

Learners should always seek the religious science represented by the Quran \& Sunna of His prophet before adopting the Sufi method. The learner must stay away from science of speech $\&$ philosophy because these impede reaching the right things.

Sixth: Methods of Teaching

Throughout the previous discussion, we find that Sufis use more than one method such as:

- Excitement \& motivation

- Individualism in learning

- Step by step learning (learners need to learn the religious sciences first and then to learn how to go through the Sufi path)

- Practical model for behavior modification

A close look at the Islamic Educational course methodology illustrates that there are numerous links between this method and the methods of Sufis (Al-Farhan, 1990). These are represented in the following principles: 
First principle of god's fear \& belief education

Second principle of integrated personality

Third principle of the social education: this methodology includes some social objectives that reinforce the group unity

Fourth principle of model learning

Fifth principle of continuing education

Sixth principle of equal educational opportunities (no discrimination between the two genders)

Seven $\quad$ principle of self purification

Eighth principle of the educational model

\section{References}

The Holy Quran

Sahih Al-Bukhari, Al-Salafeiyah Edition

Ibin Khaldoun, Abdul Rahman. (1967). Mugadamat Ibin Khaldoun (2 ${ }^{\text {nd }}$ Edition). Egypt: Al-Azhareiyah Press.

Ishteiwah, Fawzi. (1999). Athar Tareigai Al Istigsa Wa Al Ta;Leem Al Ta'awni Fi Al Tahseel Al Fawri Wa Al Mu'ajjal Lada Talabat Al Saf Al Taseh Al Asasi Fi Madat Al Tarbeiyah Al Islameiyah. Unpublished M.A. Thesis. Uinversity Of Jordan.

Badawi, Abdul Rahman. (1975). Tarikh Al Tasawif. ( ${ }^{\text {st }}$ Edition). Kuwait.

Bairouni, Abi Al Rayhan. (1958). Tahqiq Ma Llhind Min Maqwlah. India: Dar Al Ma'aref Press.

Al Tarmithi, Abi Abdullah. (1947). Al Riyadah Wa Adab Al Atfal. Egypt: Mustafa Al Babi.

Al Tasturi, Sahal Bin Abdullah. (1950). Dar Al Kutib Al Arabiyah.

Tasheer, Gold. (1970). Al Aqidah Wa Al Shari'ah. (2 ${ }^{\text {nd }}$ Edition). Egypt: Dar Al Kutib Al Hadithah.

Jalal, Mohammad. (1990). Saykologiayat Al Hayat Al Ruhaih Fi Al Islam. Dara Al Kutib Al Arabiyah.

Hilmi Mohammad Mustafa. (1945). Al Hayat Al Ruhaiyah Fi Al Islam. Dar Ihya Al Kutib Al Arabiyah. 
Al Khateeb, Abdulkareem. (1980). Al Tasawwif Wal Mutasawwifah Fi Muwajaht Al Islam. ( $1^{\text {st }}$ Edition). Dar Al Fiker Liannasher Wa Attawzee'.

Al Khateeb, Omar Odeh. (1979). Lamahat Fi Al Thaqafah Al Islamiyah. Lebanon: Musa;Ast Al Risalah.

Al Khawakdeh, Naser. Muqaranah Bayn Athar Tariqat Al Ta'llum Biliktishaf Wa Attalum Bittariqat Attaqlidiyah Ala Tahsil Attalabah Wahtifazahum Bitta'lum Fi Madat Attarbiyah Al Islamiyah Lissaf Al Awal Athanawi. Unpublished M. A. Thesis. Uinversity Of Jordan.

Al Salmi, Abi Abdul Rahman (Manuscrpt).

Al Salmi, Abi Abdul Rahman. Tabaqat Al Sufiyah. (3 ${ }^{\text {rd }}$ Edition). Egypt: Maktabt Al Khanji.

Al Shathili, Jamal Addin. (1977). Qawanin Al Hukim Alishraqiyah. Egypt: Maktabat Al Kullayat Al Azahriyah.

Al Dahi Hasan, Attayib Ahmad, Albadawi Hasan And Alasal Khalifah. (1993). Buhuth Fi Athaqafah Al Islamiyah. (1 ${ }^{\text {st }}$ Edition). Egypt: Dar Al Hikmah.

Ottoman, Abdul Kareem. (1958). Ilim Alnafis Al Aam. Saudi Arabia: Ministry Of Information.

Al Omari, Abdul Mun'im. (1990). Athar Tariqat Al Istigsa Fi Attidrees 'Ala Attahsil Wa Alihtifaz Fi Madat Dirasat Fi Afiker Al Arabi Al Islami Lada Talabat Kulyat Al Mujtama’ Fi Al Urdin. Unpublished M. A. Thesis. Uinversity Of Jordan.

Al Ghazali, Abu Hamid. (1960). Ihya' Olum Addin. (1 ${ }^{\text {st }}$ Edition). Beirut: Dar Annadwa.

Farhan, Ishaq. (1984). Al Minhaj Attarbawi Bain Al Asalah Walmuasarah. Amman: Dar Al Basher.

Al Qushairi. (1980). Al Risalah Al Qushiriyah. Egypt: Dar Al Kutib Al Arabiyah.

Mahmoud, Abdulhaleem. (1974). Attafikeer Al Falsafi Fi Al Islam. (1 ${ }^{\text {st }}$ Edition). Lebabon: Dar Al Kitab.

Al Najjar, Ibraheem, Abdullah, Saleh And Abdul Rahman. (1993). Al Thaqafat Al Islamiyah Wa Traiq Tadrisaha. ( ${ }^{\text {st }}$ Edition). Amman: Jerusalem Open University.

Nilcoln, (1951). Al Sufiyah Fi Al Islam. Egypt: Maktabat Al Khanji.

Hilal, Ibrahim. (1975). Attasawif Al Islami Bain Addin Walfalsafah. Cairo: Dar Al Nahzah.

Yaljin, Muqdad. (1976). Wasail Attarbiyah Aliymaniyah. Majalat Al Muslim Al Mu'aser. Issue 5. Beirut. 